\title{
Middle leadership in international schools: Evidence from Malaysia
}

\section{School Leadership and Management}

Vahid Javadi ${ }^{\mathrm{a}}$, Tony Bush ${ }^{\mathrm{b}}$ and Ashley, $\mathrm{Ng}^{\mathrm{C}}$

${ }^{a}$ School of Education, University of Nottingham, Semenyih, Malaysia;

${ }^{b}$ School of Education, University of Nottingham (Malaysia \& UK), Nottingham, UK;

'School of Education, University of Nottingham, Semenyih, Malaysia

\section{Middle leadership in international schools: Evidence from Malaysia}

This paper examines middle leadership of the heads of English, maths and science departments in four international secondary schools in Malaysia. It focuses on their roles, responsibilities, role relationships, instructional engagement and leadership involvement within the theoretical framework of instructional, distributed and teacher leadership. The study is a qualitative multi-method case study, involving observation, documentary analysis, and semi-structured interviews with 12 heads of department, 36 teachers, and four principals. With respect to the middle leaders' roles and responsibilities, the findings illustrate cross-school and in-school differential developments, with contextual factors contributing to uneasy role relationships. The results also show that, while broad-based leadership opportunities are limited for the middle leaders and teachers, the most powerful and common feature of all these international schools is the centrality of teaching and learning.

Keywords: middle leadership; instructional leadership; distributed leadership; teacher leadership; international schools; Malaysia

\section{Introduction}

International schools have become key players on the social and economic landscape of education in the $21^{\text {st }}$ century, with a turnover of revenue on a multibillion scale (MacDonald 2006). International School Consultancy (ISC) reports the total number of English-medium schools to be over eight thousand, serving over 4.6 million students (www.isc-r.com). Malaysia is one of many countries contributing to the development of international schools.

\footnotetext{
* Corresponding author. Email: Vahid.Javadi@Nottingham.edu.my
} 


\section{International schools in Malaysia}

The quota system is a mechanism international schools use to regulate the enrolment of local nationals. It intends to achieve an 'optimum' balance between the expatriate community and the local population (Hayden 2006). Until 2012, Malaysian international schools were legally bound to observe a 40 per cent limit on local nationals (www.schoolmalaysia.com) However, this decision was revoked (www.thestar.com.my), which led to a significant growth in international schools (Nasa et al. 2014), and an increase in the proportion of local students. According to Ramey (2013), 43 per cent of international students are local Malaysians, occasionally becoming a majority (see Javadi 2013). Bailey (2015) reports the Malaysian student population at her researched international school to be over 70 per cent, which consists of the Chinese Malaysians, as the largest ethnic group in that school, followed by the Malays and the Indian Malaysians.

The growth in demand for international schools in Malaysia, following the revocation of the 40 per cent cap, arises from several factors. Ramey (2013), for example, attributes this increase to parents' perception that studying in an English medium of instruction will aid their children to learn the language. However, in her case study school, Bailey (2015) found that this perception was more popular among the staff than the students. These mixed messages indicate the need for further empirical research in this area.

Globally, Asia tops the list of international schools (www.isc-r.com). In Malaysia, there were 70 international schools in 2012 (www.thestar.com.my), but there has been substantial growth since then, with one source (www.schooladvisor.my) estimating that there were 115 by 2016 , suggesting a growth rate of over 36 per 
cent. The nationwide development has not enjoyed equal geographical distribution, with most schools being in Selangor (41) and Kuala Lumpur (21), followed by 10 schools in Johor, bordering Singapore, and none in Perlis, bordering Thailand.

\section{Purpose of the Paper}

This paper presents and discusses research on middle leadership in four selected Malaysian secondary international schools within the framework of instructional, distributed and teacher leadership. The paper addresses the following research questions:

(1) What are the roles, responsibilities and role relationships of middle leaders in the selected international schools?

(2) How, and to what extent, are middle leaders involved in the leadership of the selected international schools?

(3) How, and to what extent, are the leadership practices undertaken by the middle leaders linked to teaching and learning in the selected international schools?

(4) How, and to what extent, can the practices of middle leaders in the selected international schools be understood through distributed and/or teacher leadership?

Following Wise (2001), we define middle leaders as practitioners who are heads of department (HoDs), manage the academic curriculum and lead a number of teachers. In this enquiry, the leadership practice of English, maths and science HoDs in four selected international secondary schools were explored.

The first research question is largely descriptive, and aims to examine the roles and responsibilities commonly undertaken by the HoDs. It also seeks to explore the quality of the relationships between the HoDs and their role sets, most notably the teachers and the principals. Research question two addresses the extent to which 
the HoDs are involved in the leadership of their schools. Research questions three and four aim to understand middle leadership practice against the backdrop of instructional, distributed and teacher leadership theories.

\section{Literature Review}

Partial privatisation of education worldwide has revealed the limited capacity of solo leadership (e.g. Crawford 2012), leading to the revitalisation of the leadership role of the middle leaders. A review of the existing literature suggests five major themes pertinent to this role, distinguished below:

- Roles

- Responsibilities

- Role relationships

- Instructional engagement, and

- Leadership involvement

\section{$\underline{\text { Roles }}$}

In the mid-1990s, Ofsted (1996), the British government's inspection unit in England and Wales, defined middle managers as practitioners who are both teachers and managers of other teachers, and, in the capacity as heads of department (HoDs), they are engaged in managing the academic curriculum (Wise 2001). Wong et al. $(2010,63)$ define middle leaders in Hong Kong as teachers with formal administrative responsibilities, and in Australia, Gurr and Drysdale (2012, 57) define them as leaders with 'significant responsibility'.

Over time, the HoDs have been recognised to be 'key figures' (Busher and Harris 1999, 307), and in England, they are described as leaders who are capable of making a significant impact on the performance of departments (Earley and Fletcher-Campbell 1989). In China, the middle leaders are 'experienced teachers' 
who enjoy a respectable position with long-term professional commitment to one school (Tam 2010, 374).

Organisationally, HoDs reside at the centre. In Jarvis's $(2008,27)$ enquiry in England, and Fitzgerald's $(2009,58)$ study in New Zealand, the HoDs describe themselves as a 'conduit' (also see Glover et al. 1998). This 'middle' position highlights the importance of role sets, and their potential influence on middle leaders. Wise and Bush (1999) suggest several role sets, notably teachers, senior leaders, parents and governors. Wise (2001) adds that, of all these, teachers tend to have the strongest influence on middle leaders (58.8 per cent), compared to 21.7 per cent of influence from their senior leaders (Wise and Bush 1999).

Tam $(2010,383)$ in China points out the 'challenging' nature of the HoDs' role. This partly arises from the department members' uncertainty surrounding the nature and the scope of an HoD's role (Jarvis, 2008), affecting departmental performance (Earley and Fletcher-Campbell 1989).

\section{Responsibilities}

There are four parameters to be considered about the HoDs' responsibilities; the nature, the scope, the priorities, and the perspectives of the senior leaders vis-à-vis the middle leaders.

Following Wise and Bush (1999), the nature of HoDs' responsibilities can be divided into four categories of academic, administrative, managerial and educative. Of these, all the responsibilities under 'managerial tasks' are highly relevant to this paper, and are shown in table 1: 
Table 1. Middle leaders' managerial tasks.

Monitoring the teaching of departmental staff

Induction of new staff

Keeping departmental staff informed of whole-school matters and encouraging debate

Development of departmental staff's professional abilities

There are some concerns about the HoDs' scope of tasks, and these include additional roles and additional responsibilities. Earley and Fletcher-Campbell (1989) found that most of the middle leaders, alongside being homeroom teachers and pastoral heads, undertook responsibilities that extended to the whole school. More than half (51 per cent) of the HoDs in Wise and Bennett's (2003) enquiry in England, and 20 per cent of the HoDs in Weller's (2001) study in the US, report additional responsibilities. Fitzgerald (2009), in New Zealand, and Ghamrawi (2010) in Lebanon, report a similar trend.

As a survival strategy, task priority may be introduced. This is evident in the rankings the HoDs provided for tasks presented to them by Wise and Bush (1999), as shown in table 2, which displays the top four priorities:

Table 2. HoDs' partial priority tasks list.

Teaching subject throughout the school

Developing the curriculum including teaching and learning strategies Implementing school policy Supervising/monitoring colleagues' work to ensure that policies are followed through

Average priority 2.56 3.47

5.40

5.42

Considering a low mean as indicative of a high priority, the table illustrates that, for the researched HoDs, the teaching role is the most important responsibility, highlighted in two intercontinental definitions in Europe (e.g. Ofsted 1996 in England) and in Asia (e.g. Wong et al. 2010 in Hong Kong). 
In their systematic review, Bennett et al. (2007) identified two paradoxical pairs that can affect the perspectives of senior managers vis-à-vis middle leaders. One of these is whole-school emphasis vs. departmental loyalty, which involves the tendency of the HoDs to ally themselves with their departmental members. This influences the HoDs' relationships with their school-based role sets, senior leaders and teachers. Brown and Rutherford $(1998,86)$ identified that part of the tensions surrounding middle leaders emanated from their reluctance to involve themselves in whole-school matters.

\section{Role relationships}

Tam (2010, 383) describes an HoD's role in China as 'challenging'. In England, Glover et al. $(1998,287)$ announce that the role of a middle leader is 'fraught with difficulty', with considerable tensions surrounding 'the nature and expectations of middle leadership' (Bennett et al. 2007, 462). In an early study, Lambert (1975) suggested the following typology, indicating the level of agreement between the headteachers and the HoDs with regard to the role functions of the latter cohort (see table 3).

Table 3. Lambert's typology of department heads' role functions.

\begin{tabular}{c|c|c|c} 
Area & $\begin{array}{c}\text { HoDs } \\
(\mathbf{\%})\end{array}$ & $\begin{array}{c}\text { Heads } \\
\mathbf{( \% )}\end{array}$ & $\begin{array}{c}\text { Index of } \\
\text { Agreement }\end{array}$ \\
\hline Instrumental academic & 85 & 92 & 0.93 \\
Instrumental institutional & 66 & 80 & 0.82 \\
Expressive institutional & 50 & 62 & 0.81 \\
Expressive academic & 67 & 89 & 0.75
\end{tabular}

As the table illustrates, only the 'expressive' quartiles attract the lowest percentage of agreement, and between these two, 'expressive academic' receives the least 
consistency, and this is the area, which according to Lambert $(1975,37)$, is 'likely to be the source of possible role-conflict'.

\section{Instructional engagement}

HoDs are part-teachers and part-leaders, and when 'outside' the classroom, they remain connected with the classroom through several means, most notably monitoring (see Blasé and Blasé 2002; Southworth 2002).

Monitoring is a managerial responsibility (Wise and Bush 1999; see table 1 above), and an important component of instructional leadership. There are two types of monitoring; formal and informal. Formal monitoring is commonly linked to appraisal, which occurs on a regular basis, by appointment, and by mutual agreement (Turner 2000). Informal monitoring, according to Glover et al. (1998), lacks rigour and may lead to insufficiently useful outcomes. Wise $(2001,338)$ deems it appropriate to approach informal monitoring as complementary to formal supervision. Alternatively, as Bennett (1995) states, some HoDs prefer to check exercise books.

There are some persisting concerns over the effective conduct of monitoring (e.g. Ofsted 1996 and 2015). First, monitoring may affect the relationships between the HoDs and the teachers (Bullock 1988; Earley and Fletcher-Campbell 1989; Wise 2001). In some cases it is described as 'risky' (Hannay and Denby 1994), with the observers regarded as "spies" (Metcalf and Russell 1997). In Lebanon, Ghamrawi (2010) reports similar concerns. Second, monitoring, as an expected 'quality assurance process' may contrast with collegiality, as a process that emphasises 'mutual learning' (Bennett et al. 2007, 462). However, the most important, and 
persistent, barrier to monitoring remains to be shortage of time (Earley and Fletcher-Campbell 1989; Adey and Jones 1997; Brown and Rutherford 1998; Wise and Bush 1999; Wise and Bennett 2003; Busher 2005; Gurr and Drysdale 2012).

\section{Leadership involvement}

Middle leadership is the embodiment of distributed leadership (DL), and by extension, teacher leadership (TL). Harris (2008) speaks favourably about the outcomes of a leadership style that is inclusive and participative. A question often asked in the leadership and management literature concerns the nature of DL. We argue that $\mathrm{DL}$ is equivalent to the autonomy for middle leaders to take important decisions, and to the authority to implement those decisions without resorting to senior leadership for permission; any subsequent sharing of decisions is pursued for the purpose of whole-school coordination.

There is growing evidence about the benefits of shared decision-making. In Hong Kong, Tam (2010) attributes the achievements of Michael, a successful HoD, to his inclusive approach of collective decision-making. Similarly, Earley and FletcherCampbell (1989) and Harris (2008) in England, Turner (2000) in Wales, Hannay and Ross (1999) in Canada, and Chang (2011) in Taiwan, speak positively about the benefits of participative leadership.

However, Adey's $(2000,427)$ study in England shows that 47.9 per cent of the participants rated their influence on whole-school policy as average, and 31.6 per cent claimed that they had 'little or no influence'. These findings resonate with Buckby's (1997) study in England, and Mercer and Ri's (2006) enquiry in China, where the middle leaders were demanding an increase in their leadership 
involvement. These findings, however, contrast with Brown and Rutherford's (1998) recognition of leadership apathy as a cause of conflict.

Similarly, in their large-scale study on teacher leadership, Xie and Shen (2013, 342) conclude that teachers in the researched public schools in the US describe their leadership involvement as 'still mainly confined to the boundary of the traditional areas of classroom'.

Middle leadership in Malaysia

There is only limited evidence on middle leadership in Malaysia. The most directly relevant research is Javadi's (2014) enquiry into middle leadership in an international school in southern Malaysia. According to Javadi, the HoDs hold diverse roles, with dominant managerial responsibilities. He reports tension in the relationships between the HoDs and the senior managers, where most criticisms are directed at lack of autonomy. The HoDs are reluctant to conduct lesson observations, and resort to alternative methods such as checking worksheets. Lack of time continues to hamper the work of the HoDs at this school. According to Javadi, the majority of the HoDs do not perceive themselves as leaders of their departments. None of the middle leaders had received any formal training, relying, instead, on learning on the job. Evidence from this school in Malaysia is largely consistent with the international literature on middle leadership practice (e.g. Earley and Fletcher-Campbell 1989, Bennett 1995, Glover et al. 1998, Wise and Bush 1999, Adey 2000, and Wise and Bennett 2003 in England; Weller 2001, and Xie and Shen 2013 in the USA; Hannay and Denby 1994 in Canada; Gurr and Drysdale 2012 in Australia; Fitzgerald 2009 in New Zealand; Ghamrawi 2010 in Lebanon; Mercer and Ri 2006, and Tam 2010 in China). 


\section{Methodology and Methods}

The research methodology employed in this study was qualitative in nature, and interpretivist in orientation, with an emphasis on seeking practitioners' views on the practice of middle leadership. A case study approach was deemed appropriate to permit in-depth access to the various areas of interest to this study. A salient feature of case studies is the possibility of employing multiple methods, most notably interviews, observations and documentary analysis.

An important issue in qualitative research is credibility, a.k.a. internal validity. This technique is used to increase the likelihood of the collection of healthy data (Flick 2009, 257). A major strategy to increase credibility of research is through triangulation (Bryman 2008), which operates on the logic of juxtaposing sources of information to ascertain their accuracy (Bush 2002). The possibility of using multiple methods in case study approach (e.g. Robson 2002) leads to methodological triangulation, which enables the possibility of comparing the accessed sources of information (Bush 2012).

\section{Interviews}

Interviews are the most common method of data collection (King 2004), and provide access to the phenomena, as conceived by humans (Arksey and Knight 1999). Semi-structured interviews were used to glean individual perceptions on a matter (Flick 2011). Follow-up questions and probes, an essential feature of semistructured interviews, were also used to develop an in-depth understanding of an issue (Coleman 2012). 
An interview guide was designed for each role set, containing four sections, linked to the research questions; roles and role relationships, leadership involvement, instructional engagement, as well as opinions and feelings about the school and departmental leadership. The interviews lasted between 45 minutes and one hour, and informed consent was sought and, the participants agreed to record the interviews.

\section{Observation}

Unlike interviews, observations provide powerful evidence of what people do. Of the several types, the 'observer-as-participant' (e.g. Punch 2009) was used to permit 'superficial' access (Waddington 2004, 154), complemented by in-depth interviewing (see above). Observations were used to understand the extent to which interactions were professional, attention was focused on teaching and learning, and leadership was decentralised. An observation schedule was created with blocks of 15 minutes (see Denscombe 2010, 200) for the activities in the staffrooms and in staff and/or departmental meetings.

\section{Documentary analysis}

Documents usefully provide access to the underlying sophisticated world of organisations (Bryman 2008). The most common documents available in schools, and used in this enquiry, are 'policies' (Fitzgerald 2012), e.g. role descriptions, or 'records of meetings' (Denscombe 2010), e.g. minutes, as well as staff handbooks.

Data from the documents, the observations and the interviews enabled a comprehensive picture of middle leadership practice in the four selected international secondary schools in Malaysia. 


\section{Sampling}

Sampling for this study took place at two levels; sites and participants.

\section{Sites}

A search in School Advisor (www.schooladvisor.my) generated 21 schools in Kuala Lumpur. To avoid sampling error, which occurs as a result of discrepancies between the population and the sample size (Bryman 2008), stratified sampling was employed. This technique works upon the logic of the higher the homogeneity of a sample size, the more the accuracy of findings (see Kumar 2011), and this was achieved through the following criteria:

- Secondary school

- Curriculum type, i.e. the British IGCSE Curriculum

- Predominantly Malaysian staff

Schools that failed to meet these requirements were eliminated, yielding a stratum of eight schools $(n=8)$. However, the aim was for four, a number considered to be feasible in terms of time and research design. To achieve this, scrutinising the web pages of these eight schools was chosen as the primary point of contact. Of these, two sites were eliminated, as they were in the process of recruiting new principals, yielding a stratum of six schools $(n=6)$. This figure was subsequently reduced to four as, of the six potential sites, only four consented to this research, hence $n=4$.

\section{Participants}

It was crucial to contact practitioners who would be in possession of and willing to share information pertinent to their profession (Kumar 2011). This non-probability strategy is called purposive sampling, which was used to determine target departments as well as participants. 
Traditionally, maths, science and languages - English in this study - have been central to schooling, and their results alone are used by the Programme for International Student Assessment (PISA) (www.oecd.org/pisa). To contact the HoDs of these departments, the principles of 'relevance' and 'knowledge' were considered, which are both central to purposive sampling (Denscombe 2010). Furthermore, the authors agreed that a sample size of three teachers in each department would provide a comprehensive understanding of middle leadership practice. However, recalling the fluidity of the staff at international schools, unless the targeted teachers had been in post for some time, such an understanding would not be fully achievable. Therefore, snowball sampling was used, the starting point of which is from 'a known network' (Dattalo 2008,6), which in this case, was the HoDs who would recommend their long-serving colleagues. However, this strategy was unnecessary in schools $B, C$ and $D$ as the number of participants required precisely matched the number of teachers available.

In total, 12 HoDs, 36 teachers and four principals $(n=52)$ agreed to participate in this research, enabling respondent triangulation. This strategy is used to address the issue of credibility (internal validity), as noted above, through eliciting information from multiple stakeholders.

\section{Data analysis}

In this enquiry, data collection and analysis received contemporaneous attention (e.g. Hesse-Biber and Leavy 2011). Data were reduced (see Miles and Huberman 1994), using two key techniques; coding (Cassell and Symon 2004) and memoing (Bryman 2008). In this study, the codes and memos used were consistent with the 
five main themes of middle leadership identified in this study; roles, responsibilities, role relationships, instructional engagement and leadership involvement.

Departments were the primary units of analysis, and received substantial analytical treatment. This approach enabled comparison of middle leadership practice in individual departments within each school, and across the four schools.

\section{Findings and Discussion}

This section presents an integrated thematic discussion of the findings of the casestudy international schools with respect to roles, responsibilities, role relationships, instructional engagement and leadership involvement.

\section{Roles and responsibilities}

The examination of roles in the four schools involved documentary analysis and interviews. These data point to three important conclusions. First, while middle leadership is perceived to be well-established at schools A, D, and C, it is loosely defined and poorly understood at school B, as described by the English HoD:

Initially I was supposed to be the A-level coordinator, but the person who was the English HoD left, and it just slid over to me. It was never defined to me; it was just a given title. I have no job description. I have no idea what the role involves.

This finding lends support to the conception of differential cross-school development of departments. Second, within a single school, departments may display varying stages of development. For example, the English department at school $A$, and the science departments at schools $D$ and $C$, were perceived to be faring better than the other departments in the same school. In school B, where middle leadership is ill-defined, the English department was found to be the least 
effective, as evident in this teacher's remark: 'I like the school because no one comes and tells me what to do. I can do whatever I want. There is freedom in this school'.

Finally, the consistent grand picture from the cross-case data analyses indicates that middle leaders' role conceptions, within and across the four schools, tend to be arbitrarily defined and subjectively interpreted, leading to differential, and inconsistent, middle leadership practice. The documents in the four schools articulate the formal organisational expectations of the HoDs. They require that the HoDs be 'excellent teachers' (school A) with 'relevant expertise' (school B) and 'full weekly teaching load' (school C) who 'take responsibility for teaching and learning' in their schools (school D) (see Wise 2001). These phrases serve to highlight the importance of teaching and learning for these schools, and echo the priority of teaching for Wise and Bush's (1999) researched HoDs (see table 2). Emphasis on teaching also highlights the dominance of managerial responsibilities (see table 1), as reflected in this comment by the maths HoD at school C:

I have to go and make sure that the lessons are conducted well; students [and] teachers are happy; they have all the materials [and] resources. [I also] check their classes. That's what I have been doing since I was appointed as HoD.

These circumstances lead to the conclusion that 'middle management' continues to frame the roles and responsibilities of the participating HoDs, undermining the notion of 'middle leadership' in the title of this paper (see Buckby 1997; Adey 2000; Mercer and Ri 2006).

Hierarchically, HoDs are situated in the 'middle'. In all the schools, a middle leader is described as a 'facilitator', 'messenger', 'spokesperson', 'go-between' (school A), 
'inspector' (school B), 'intermediary', 'coordinator', 'facilitator' (school C), 'organiser', 'supervisor', 'middle person', 'representative', and 'bridge' (school D). According to the participants, a leader in this position is expected to 'fight', 'take care', 'support', 'link', and 'pass messages' between the 'top' and the 'bottom'. Although different participants chose to select distinct terms to describe their HoDs, they all allude to the 'conduit' role of the middle leaders, re-echoing earlier claims (e.g. Glover et al. 1998; Jarvis 2008; Fitzgerald 2009):

[The HoD position is] sort of go-between for senior leadership and teachers ... to help facilitate the school moving forward with some direction from their senior leaders. (The head of secondary at school A)

Head of department is usually a coordinator ... a coordinator or facilitator of things. (A science teacher at school C)

[The HoD is] a bridge between the top management and the teachers to convey any messages and information. (A maths teacher at school D)

The distinction between the formal role articulations in the staff handbooks, and the role comprehension by individuals, uttered in the interviews, especially at school C, led to the emergence of the 'visibility' and 'invisibility' dichotomy. 'Visibility' can be used to describe the immediate services which teachers receive from their HoDs. Conversely, 'invisibility' can be used to describe the services which teachers do not receive from their HoDs when they are expecting them. These situations are most likely to occur when, even if available, the official staff handbooks are rarely consulted, as was the case with all the participants in these four schools.

Middle leaders' roles and responsibilities at schools D and B are special, and hence, require further attention. In the relatively new school $D$, middle leadership activities are strongly influenced by the 'tyranny' of the heavy timetable, restricting leadership activities other than teaching: 
... very heavy timetable that we've all got. I've got only two free periods a week where none of us are teaching ... there's no space anywhere to think properly. (The English HoD at school D)

This may account for the dominance of the teaching role for the HoDs in this school (see Wise and Bush 1999, table 2 above). In school B, however, middle leadership activities are overshadowed by the noticeable presence of the principal, leading to a loose understanding of middle leadership. The only reference in the staff handbook consists of a few lines. What unites, or otherwise, the HoDs with the principal is unclear, but what is certain is that it is not their role. This makes it difficult to discuss middle leadership in terms of departments because such a concept barely exists in the minds of the participants at this school. These circumstances have forced them to rely on the principal for accessing 'accurate' information:

Almost all the decisions are approved by the principal. So, I can't be simply giving instructions because I have bigger people than me here, so I consult them before I give orders to [the teachers]. (The science HoD at school B)

The variations in the middle leadership practice, and the differences in understanding the role are not limited to the school level; they also extend to the department and individual levels, leading to extensive uncertainty (e.g. Earley and Fletcher-Campbell 1989; Jarvis 2008), and abundant personal judgements.

\section{Role relationships}

Factors influencing the relationships between the HoDs and their school-based stakeholders are varied and distinct, and these include concerns over attitude (school A), principal's dominance (school B), unstable senior leadership (school C) and tenure (school D), confirming claims by Glover et al. (1998), and Bennett et al. (2007), that the middle leadership role is replete with tension. 
The picture that emerges from the data suggests that concerns about the middle leaders' behaviour and attitude outnumber those expressed about their knowledge and expertise. Half of the $12 \mathrm{HoDs}$ are confidently admired for their knowledge and expertise. In contrast, most of them, that is the nine HoDs at schools $A, B$ and $C$, are blamed, although variously, for their behaviour and attitudes:

Some of them [teachers] I find quite pushy in a sense that, when I say let's do this, then someone has a suggestion to do something else. (The HoD at school A)

I may disagree with a lot of things she says, [but] whenever we raise concerns she doesn't really listen to us; I feel I can't work. (An English teacher at school A)

This conception is consistent with Lambert's $(1975,37)$ finding that the 'expressiveacademic' section of his typology is an area which is 'likely to be the source of possible role-conflict'.

At school $D$, the HoDs are the only leaders who are consistently praised. This is not because they are brilliant leaders, or exercise leadership in its most inclusive fashion, but because, being in a new school, they have not yet had the opportunity to abandon the 'safe' domain of the classroom and department to experience the 'less comfortable' domain of active and broad-based consultative leadership, which is characteristically complex and challenging:

So far it's good. I mean we do go out, and have some drinks, and at school, [the HoD] is professional ... she's very supportive. (An English teacher at school D)

In school B, the quality of the relationships has been affected by overdependence on the principal. Given the reported and observed tense relationships between some of the participants, as well as the other members of staff, and in the absence 
of a departmental identity, the quality of the participants' relationships with the principal has gained considerable significance:

I think they [the teachers] cannot immediately go to the principal and talk to her. You know, as a teacher, you cannot knock on her door and immediately talk to her. (The maths HoD at school B)

This may explain that why, despite tense relationships, all the participants expressed satisfaction with the principal, although less so with the way the school was managed.

A certain degree of 'subdued' resentment could be discerned among the participants in school C - a sort of unexpressed 'concord' that had convinced them to take refuge in their isolation. Considering the leadership history of school C, with eight principals since the late 1990s, the participants' behaviour might be regarded as a legitimate response to this highly volatile leadership trajectory. The participating teachers are not at odds with their HoDs; they and their HoDs are all victims of unstable leadership. According to the interview data, the average tenure of the HoDs is about eight years. Thus, what these three departments represent is a relatively stable middle leadership, as opposed to a history of unstable senior leadership, which continues to be a source of concern at this school:

The owners of the school like to micromanage, and he [the head of secondary] has been here for a short time. I don't think they trust him yet. (An English teacher at school C)

If the directors and the owners let us run the school, we'll flourish. If they put restrictions on us, and keep interfering, then we'll go backwards again to where it was. (The head of secondary at school C)

The quality of the relationships in school $D$ is a function of tenure. The science HoD has the longest length of service - since 2014 and for two years. Although the 
maths HoD has also been in this school for two years, she was only promoted to this position in 2015, when both the head of secondary (HoS) and the English HoD were recruited. Interview and observation data found both the science HoD and the HoS on favourable terms with each other:

The science HoD has done a fantastic job. She is leading [the department] in the right direction; definitely she's experienced [and] knowledgeable, and she's got great vision. (The head of secondary at school D)

This positive relationship can be understood in the context of the support and advice the former is able to provide to the latter due to her familiarity with the school's structure and processes from the beginning. This was evident from the frequent visits the HoS made to the science lab. Although both the English and the maths HoDs joined the leadership team at the same time, the advantage of the latter, a Malaysian leader, for the HoS is her familiarity with the local context:

I think the head of secondary is very supportive ... I have a very good relationship with him. So far everything is good because there is somebody who is willing to listen. (The maths HoD at school D)

I think there are still bits of communication that we haven't been clear with her [the English HoD], and she's not sure about all the aspects of her role. That's understandable because she's been here for a few months. (The head of secondary at school D)

In broad terms, the evidence about conflicts between the HoDs and the teachers, as well as the HoDs and the principals, contrasts with Wise and Bush's (1999) findings about departmental loyalty. These authors report that 58.8 per cent of the HoDs in their research chose to ally themselves with their departmental staff, compared to 21.7 per cent of influence they tend to accord their senior leaders. The evidence from this study does not seem to reflect this. On the contrary, there 
seems to be more agreement between the HoDs and their senior leaders than between the HoDs and the teachers:

Very good; I just go into the room and discuss with them [senior managers]. There are no barriers or pressures to keep quiet. I just voice [my concerns] and I think they are good at listening to our opinions. (The maths HoD at school A)

There's very much an open door policy here. [The head of secondary] can come in any time he wants to pass on some information, or he wants my opinion about something, and I feel like that I can just walk into his office. (The science HoD at school D)

The explanation for this discrepancy may be that, unlike Wise and Bush's enquiry in public schools, the research in this paper takes place in private schools, at the centre of which lie accountability, fees and parents. These may have convinced the HoDs at all the schools to align themselves with the senior management team and not so much with the teachers (see the discussion below for more on this point).

\section{Instructional engagement}

Of the themes guiding instructional leadership, the evidence focuses mainly on monitoring (e.g. Blasé and Blasé 2002; Southworth 2002). When compared to the existing empirical literature, the general picture about lesson observations provides mixed messages. In contrast to the concerns expressed by Ofsted $(1996,2015)$, Bullock (1988), Earley and Fletcher-Campbell (1989), Hannay and Denby (1994), Metcalf and Russell (1997), Wise (2001), Bennett et al. (2007) and Ghamrawi (2010), the notion of lesson observation in these schools is found to be the least contentious area, but with variations in terms of development. According to the documentary analysis, supported by the interviews, monitoring in schools A and D 
has received sufficient attention, but this is largely under-developed at schools B and C:

[The HoD is expected to] appraise staff as required by the school policy and use the process to develop the personal and professional effectiveness of teachers. (School A's staff handbook, section 6: managing performance)

[The HoD is expected] to assist in the observation of subject teachers to identify strengths and weaknesses in the teaching of the subjects he/she is in charge of. (School D's staff handbook, clause 2: observe teachers)

Moreover, contrary to the findings by the afore-mentioned authors, the participating teachers tend to accept their HoDs' monitoring roles with little resistance, and tend to view them as a common feature of their job descriptions. A science teacher at school A has this to say about the inadequacy of one-lesson observations:

I do not agree with this because there are some teachers who prepare one lesson for the observation. I think that every lesson you should be able to observe, and the head [of department] should actually observe more lessons to get an overall view. It's not really fair.

This remark reinforces the claim above that the HoDs tend to align their leadership activities with organisational requirements rather than departmental fervour. Significantly, this finding also coheres with Wise and Bush's (1999, 192) understanding to hold 'external pressure' responsible for their researched HoDs' increasing attention to monitoring (see table 2), exerted in England through Ofsted inspections, and in the case of this study in Malaysia, by parents as fee-paying clientele. Parents' opinions are taken very seriously across the four case studies so much so that school D's head of secondary felt compelled to conduct lesson observations in his new school: 
Yes, I've done that on a number of occasions. It's important because I feel there are some teachers who have limited experience ... Therefore, it has an impact on learning ... on progress [and] on what students go home and communicate to parents.

Arguably, the most powerful feature of school A lies in its supervision of teaching and learning. It conducts formal lesson observations, based on mutual agreement, and linked to performance management, as well as informal drop-ins, known as 'learning walks', on an ongoing basis, and throughout the academic year, which echo the systems and mechanisms described by Glover et al. (1998) and Turner (2000):

I've done two formal observations of every member of the department this year ... we also have a programme this year called 'learning walks', so a member of the senior management team plus a head of faculty would normally at least once a week go on multiple learning walks which would involve dropping in on anywhere between four, six or seven lessons in a day for only 5 to 10 minutes to just make a note of what was going on and then feed back to the teacher what was in there of good practice (The English HoD at school A)

The learning walks model pursues two goals. First, it creates opportunities for interdepartmental observation and learning, enabling, for example, a science teacher to visit a language classroom, and vice versa. Second, it could potentially serve as an antidote to 'showcase' lessons, as it is exercised on the basis of surprise visits. A 'showcase' lesson is one that is exclusively planned to satisfy an observer, and may depart, to a small or large extent, from the norm: 'Some teachers know that, when I'm coming, they will put up a show' (the science HoD at school A). The supervision processes are uniformly understood by the participants and routinely exercised by all the HoDs. The staff handbook contains several detailed sections that clearly articulate the instructional expectations and performance indicators. This contrasts 
with the absence of a distinct document on professional behaviour, and serves to cohere with the view above that instruction (subject knowledge) is taken more seriously than behaviour (attitude). Moreover, alternative methods, such as checking exercise books, are also used in school A (e.g. Bennett 1995):

The Head of Department will be able to implement and supervise an effective system to check student's written work by way of checking books and challenge teachers about any errors or inconsistencies in marking. (School A's staff handbook, section 3: assessment and evaluation)

Similarly, school D tends to place great emphasis on instruction so that all the other aspects of school leadership are either aligned with this, or have been affected by it. The formal and informal monitoring models in school $D$ resonate considerably with the systems in place in school A, albeit at a lower degree of rigour due to the young age of this school, and its heavy timetable: 'I do one formal observation myself; I do half term, which they get feedback from. I also do drop-ins for 10 minutes of their lessons' (The science HoD at school D).

Monitoring of teaching and learning at school B also receives attention, but this is limited compared to schools $A$ and $D$, where there are some criticisms. Commenting on the 'surprise' nature of classroom visits at school B, a science teacher remarked that 'it would have been a little more polite to have let me know earlier' rather than 20 minutes before the start of his lesson. Despite some observed irregularities, such as high teacher absenteeism - seven in one instance - leaving some classes unattended and indicating poor relief management, school B seems to be conscious of the importance of quality instruction, and thus, pays attention to formal lesson observations. One distinctive feature of monitoring in this school is its 'dualobserver' system, where two observers, one essentially being the subject expert, 
visit a lesson and provide feedback. Although the overall observation timescale is announced, the actual classroom visits remain unannounced, with a view to capturing authentic content delivery, and discouraging showcase lessons:

Because sometimes when we tell the teachers that we're going to class, they will prepare. We want to see what actually they are doing in normal classes. (The science HoD at school B)

Questions about formal monitoring at school C received mixed responses, which led the researcher to seek information from various role sets. Nevertheless, the interview data suggest a similar model to that of school A. However, at the time of this research, the school was engaged in seeking accreditation from an international body, which had caused a moratorium on lesson observations. Also, alternative methods, such as checking exercises books, receive encouragement in the staff handbooks (see Bennett 1995).

As the data above indicate, all the case-study schools conduct formal lesson observations, while schools $A$ and $D$ also undertake informal monitoring. Both Southworth (2002), and Blasé and Blasé (2002), highlight the benefits of informal interactions in improving the quality of teaching, and both these authors are silent on the issue of formal observations. Despite this, Glover et al. (1998) are sceptical about the effectiveness of informal monitoring, and Wise (2001) suggests a combination of both formal and informal observation methods, as in schools A and D. Moreover, as stated by Bennett (1995) in England, and Javadi (2014) in Malaysia, there are indications that in schools A, C and D, the HoDs rely on alternative methods, such as checking exercise books, to monitor instructional quality. 
Time constraints are frequently cited as a barrier to the monitoring role of middle leaders (Earley and Fletcher-Campbell 1989; Adey and Jones 1997; Brown and Rutherford 1998; Wise and Bush 1999; Wise and Bennett 2003; Busher 2005; Gurr and Drysdale 2012). The findings from the four case-study schools suggest that middle leaders' teaching role continues to dominate their job scope, albeit to varying degrees. This is consistent with Wise and Bush's (1999) evidence about the very limited leadership time allocations for the HoDs. The most affected school is D, with HoDs who have trouble finding a balance between their heavy teaching load and their formal and informal monitoring responsibilities. The data indicate that impediments to quality control are not necessarily limited to school-based factors. School C is a good example of the impact that an external intervention, the accreditation project, can have on the internal functions of the HoDs.

In general, however, monitoring is the most powerful feature of these schools, but it constitutes only one component of instructional leadership. Evidence of other elements of instructional leadership, for example, modelling and mentoring, is very limited at these four case-study schools.

\section{Leadership involvement}

As noted earlier, middle leadership is the embodiment of distributed leadership, and by extension, teacher leadership. Conceptions about the HoDs', and the teachers', leadership roles can be analysed by making a distinction between 'serious' and 'less serious' issues.

During the field work in all the four schools, it became clear that the HoDs' autonomy may be applied differentially for 'serious' and 'less serious' categories. In 
broad terms, 'less serious' matters are linked to teaching and learning, and confined to the classroom domain. In contrast, 'serious' issues pertain to policies, and operate beyond the boundary of the classroom or the department. For the former category, the HoDs claimed, and were reported to have, a greater measure of autonomy, compared to the latter category, for which opportunities were said to be limited:

Only if it is a very drastic change ... she [the HoD] still has to ask the principal ... it depends how serious or how much it concerns the parents or the whole school. (An English teacher at school A)

We can take a decision for small things, but if we have a bigger problem, we should consult [the principal]. (The maths HoD at school B)

If it's something very simple that does not involve costs to the management or the directors or the owners of the school, then I think that is fine. So, that depends on the sort of issues or things on the table. (The science HoD at school C)

Like for the activities, [e.g. book week and trips], we can actually decide and implement them, but things like the budget ... we have to get the principal's approval. (An English teacher at school D)

Evidence from school A suggests that three elements inform the extent to which a matter is considered serious or otherwise; task type, location, and people. For example, if a specific task should take place outside the classroom, and it involves parents, it should then be a serious matter, for which broad-based leadership opportunity is limited. On the contrary, if a particular task should occur inside the classroom, which involves students, it should then be a less serious matter, for which there are more opportunities for participative leadership. In short, there is more possibility for distributed and teacher leadership within the domain of the classroom, and much less so outside this domain, confirming evidence from Buckby (1997) and Adey (2000) in England, Mercer and Ri (2006) in China, and Javadi 
(2014) in Malaysia, that middle leaders continue to have limited opportunities for a wider leadership role. Similar distinctions began to emerge at school B, despite the concentration of leadership in the figure of the principal. Wider leadership was also limited at school C, where there had been multiple leadership successions, and at school $D$, where it was constrained by a heavy teaching load.

Distributed leadership and, by extension, teacher leadership entail two important dimensions; the power to make decisions and the authority to implement those decisions without the need to seek permission from senior leaders. However, the HoDs, especially at schools $A$ and $D$, preferred to consult their superiors, and offered several reasons for this choice. One reason, given by the English HoD at school A concerns accountability, which caused her to feel compelled to avoid 'creating problems for the school' or 'creating any major logistical challenges'. Another reason implies a 'face-saving' attempt to preclude embarrassing situations. Both the English HoDs at schools $A$ and $D$ said that they chose to seek their superiors' views in order not to find out later that they were not allowed to proceed with what they had finalised with their teachers:

If I want to rethink the scheme of work per forma and what's included on it ... I don't want to say to my team that I've decided we're going to do this ... and then two, three, [or] four months down the line the senior management say this is the new per forma we're using, and I've just made them [the teachers] do the job twice. So that's [why] I'm holding back. (The English HoD at school D)

The final reservation contains cultural overtones. For example, the maths HoD at school A felt that it would be disrespectful if he tried to bypass the assistant HoS to reach the HoS: 
I think, as a professional, there should be a proper channel. For example, if my teachers wanted to implement or suggest something, I think they ought to let me know first ... at least I'm aware. I think if you jump the channel, it's not very respectful.

Similar views were expressed by teachers, particularly in schools A and D. The rationale behind this preference can broadly be divided into two categories; technical and cultural. Technical consultation takes place with the HoDs, and/or senior teachers, for their ideas, experience, and knowledge; one goal of this, in the words of a teacher at school A, is for standardisation purposes. Culturally speaking, some other teachers consider consultation with the HoDs 'out of respect' (school A), and 'the right way to do [things]' (school D).

The picture that emerges from these four schools points to restrictive conceptions and barriers for the HoDs and the teachers to exercise leadership in the manner that characterises distributed and teacher leadership in their most collegiate form. This evidence, from Malaysia, confirms research in the USA where teachers, and by extension HoDs, describe their leadership involvement as 'still mainly confined to the boundary of the traditional areas of classroom' (Xie and Shen 2013, 342).

\section{Conclusion}

This paper reports findings of a six-month enquiry into middle leadership practice at four selected international secondary schools in Malaysia. Studies pertinent to middle leadership and international schools are growing. However, in Malaysia, the evidential base is extremely limited. Therefore, this study is the first major examination of middle leadership in Malaysian international schools, and claims substantial contributions. 
The evidence from these four case study schools undermines the use of 'leadership' to refer to the activities undertaken by the participating HoDs. Alternatively, and despite calls for 'leadership', as early as in the 1980s (e.g. Earley and FletcherCampbell 1989), 'management' seems to be a more appropriate term. The instructional responsibilities of the middle managers in this study tend to take top priority. Their role is understood in fragments, leading to the emergence of the 'visibility/invisibility' dichotomy. Lack of clarity of roles and responsibilities, especially at schools $A$ and $D$, has resulted in the development of arbitrary relationships, to which considerations such as the dominance of the principal at school B, and leadership instability at school C, can be added. Leadership participation across the four schools was found to be a function of three parameters; task type, location and people, leading to the introduction of the 'serious/less serious' dichotomy, indicating that the most serious cross-school decisions fall within the remit of the senior leader. However, instruction, and the monitoring aspect of instructional leadership, continue to be the most powerful features of these case study schools.

There are several lessons to draw from these findings. First, despite expectations about the diversity of international schools, the evidence suggests somewhat uniform practices. For example, in all these schools, roles lack clarity, instructional responsibilities dominate, and complaints about professional attitudes prevail. Although instructional quality is valued, through formal and/or informal monitoring mechanisms, broad-based leadership remains limited for middle managers and teachers. Second, the great majority of previous studies on middle leadership and management were conducted in public schools, not in the international school 
sector. The findings of this enquiry are largely consistent with the international literature, reinforcing this assumption that bearing 'international' in the names of schools does not necessarily mean a significant difference. Conversely, there are great similarities between the middle leadership activities undertaken in international schools and with those in their public counterparts. The final lesson to be learned from this study resonates with Ribbins's $(2007,27)$ view that 'we should not assume that, just because time has changed, things are necessarily significantly different'.

\section{References}

Adey, K. 2000. "Professional Development Priorities: The Views of Middle Managers in Secondary Schools." Educational Management Administration \& Leadership 28 (4):419-431. doi: 10.1177/0263211X000284005.

Adey, K., and J. Jones. 1997. "The Professional Development Coordinator: Obstacles to Effective Role Performance." Educational Management \& Administration 25 (2):133-144. doi: 10.1177/0263211X97252003.

Arksey, H., and P. Knight. 1999. Interviewing for Social Scientists. London: Sage.

Bailey, L. 2015. "The Experiences of Host Country Nationals in International Schools: A Case-study from Malaysia." Journal of Research in International Education 14 (2): 85-97. doi: 10.1177/1475240915590557.

Bennett, N. 1995. Managing Professional Teachers: Middle Management in Primary and Secondary Schools. London: Paul Chapman.

Bennett, N., P. Woods, C. Wise, and W. Newton. 2007. "Understandings of Middle Leadership in Secondary Schools: A Review of Empirical Research." School Leadership \& Management 27 (5):453-470. doi: 10.1080/13632430701606137.

Blasé, J., and J. Blasé. 2002. "Teachers' Perceptions of Principals' Instructional Leadership and Implications." Leadership and Policy in Schools 1 (3):256-264. doi: $10.1076 /$ Ipos.1.3.256.7892.

Brown, M., and D. Rutherford. 1998. "Changing Roles and Raising Standards: New Challenges for Heads of Department." School Leadership \& Management 18 (1):75-88. doi: 10.1080/13632439869781.

Bryman, A. 2008. Social Research Methods. Oxford: Oxford University Press.

Buckby, R. 1997. "Enhancing School Effectiveness through Heads of Department." Management in Education 11 (4): 26-28.

Bullock, A. 1988. Meeting Teachers' Management Needs. Ely: Peter Francis.

Bush, T. 2002. "Authenticity - Reliability, Validity and Triangulation." In Research Methods in Educational Leadership and Management, edited by M. Coleman and A.R.J. Briggs, 59-72. London: Sage. 
Bush, T. 2012. "Authenticity in Research: Reliability, Validity and Triangulation." In Research Methods in Educational Leadership \& Management, edited by A.R.J. Briggs, M. Coleman and M. Morrison, 75-89. London: Sage.

Busher, H. 2005. "Being a Middle Leader: Exploring Professional Identities." School Leadership \& Management 25 (2):137-153. doi: 10.1080/13632430500036231.

Busher, H., and A. Harris. 1999. "Leadership of School Subject Areas: Tensions and Dimensions of Managing in the Middle." School Leadership \& Management 19 (3):305-317. doi: 10.1080/13632439969069.

Cassell, C., and G. Symon. 2004. "Promoting New Research Practices in Organisational Research." In Essential Guide to Qualitative Methods in Organisational Research, edited by C. Cassell and G. Symon, 1-10. London: Sage.

Chang, I. 2011. "A Study of the Relationships between Distributed Leadership, Teacher Academic Optimism and Student Achievement in Taiwanese Elementary Schools." School Leadership \& Management 31 (5):491-515. doi: 10.1080/13632434.2011.614945.

Coleman, M. 2012. "Interviews." In Research Methods in Educational Leadership \& Management, edited by A.R.J. Briggs, M. Coleman and M. Morrison, 250-265. London: Sage.

Crawford, M. 2012. "Solo and Distributed Leadership: Definitions and Dilemmas." Educational Management, Administration \& Leadership 40 (5):610-620. doi: $10.1177 / 1741143212451175$.

Dattalo, P. 2008. Determining Sample Size: Balancing Power, Precision, and Practicality. New York: Oxford University Press.

Denscombe, M. 2010. The Good Research Guide: For Small-scale Social Research Projects. Maidenhead: Open University Press.

Earley, P., and F. Fletcher-Campbell. 1989. "Managing School Departments and Faculties: Towards Better Practice." Educational Research 31 (2):98-112. doi: $10.1080 / 0013188890310202$.

Fitzgerald, T. 2009. "The Tyranny of Bureaucracy: Continuing Challenges of Leading and Managing from the Middle." Educational Management, Administration \& Leadership 37 (1):51-65. doi: 10.1177/1741143208098164.

Fitzgerald, T. 2012. "Documents and Documentary Analysis." In Research Methods in Educational Leadership \& Management, edited by A.R.J. Briggs, M. Coleman \& M. Morrison, 296-308. London: Sage.

Flick, U. 2009. An Introduction to Qualitative Research. London: Sage.

Flick, U. 2011. Introducing Research Methodology: A Beginner's Guide to Doing a Research Project. London: Sage.

Ghamrawi, N. 2010. "No Teacher Left Behind: Subject Leadership that Promotes Teacher Leadership." Educational Management, Administration \& Leadership 38 (3):304-320. doi: 10.1177/1741143209359713.

Glover, D., D. Gleeson, G. Gough, and M. Johnson. 1998. "The Meaning of Management: The Development Needs of Middle Managers in Secondary Schools." Educational Management, Administration \& Leadership 26 (3):279292. doi: $10.1177 / 0263211 \times 98263006$.

Gurr, D., and L. Drysdale. 2012. "Middle-level Secondary School Leaders: Potential, Constraints and Implications for Leadership Preparation and Development." 
Journal of Educational Administration 51 (1):55-71. doi: $10.1108 / 09578231311291431$.

Hannay, L.M., and M. Denby. 1994. "Secondary School Change: The Role of Department Heads." Paper presented at the annual meeting of the American Educational Research Association, New Orleans, LA, April 4-8.

Hannay, L.M., and J.A. Ross. 1999. "Department Heads As Middle Managers? Questioning the Black Box." School Leadership \& Management 19 (3):345-358. doi: $10.1080 / 13632439969096$

Harris, A. 2008. Distributed Leadership: Developing Tomorrow's Leaders. Abingdon: Routledge.

Hayden, M.C. 2006. Introduction to International Education: International Schools and their Communities. London: Sage.

Hesse-Biber, S.N., and P. Leavy. 2011. The Practice of Qualitative Research. London: Sage.

Isc-r. 2016. Market growth by region (online). Accessed October 20, 2016. http://www.isc-r.com/.

Jarvis, A. 2008. "Leadership Lost: A Case Study in Three Selective Secondary Schools." Management in Education 22 (1):24-30. doi: $10.1177 / 0892020607085627$.

Javadi, V. 2013. The role of principal in privately owned international schools. Unpublished paper, Semenyih: University of Nottingham, Malaysia (online). Accessed January 5, 2017. https://www.researchgate.net/publication/269409029_The_Role_of_Principals_i n_Privately_Owned_International_Schools.

Javadi, V. 2014. The role of middle managers: lessons from an international secondary school. Unpublished dissertation, Semenyih: University of Nottingham, Malaysia (online). Accessed January 5, 2017.https://www.researchgate.net/publication/269401045_The_Role_of_Middl e_Managers_Lessons_from_an_International_Secondary_School.

King, N. 2004. "Using Templates in the Thematic Analysis of Text." Essential Guide to Qualitative Methods in Organisational Research, edited by C. Cassell and G. Symon, 256-270. London: Sage.

Kumar, R. 2011. Research Methodology: A Step-by-step Guide for Beginners. London: Sage.

Lambert, K. 1975. "Research Report: The Role of Head of Department in Schools." Educational Administration 3 (2):27-39. doi: 10.1177/174114327500300207.

MacDonald, J. 2006. "The International School Industry." Journal of Research in International Education 5 (2):191-213. doi: 10.1177/1475240906065618.

Mercer, D., and L. Ri. 2006. "Closing the Gap: The Role of Head of Department in Chinese Secondary Schools." Educational Management, Administration \& Leadership 34 (1):105-120. doi: 10.1177/1741143206059541.

Metcalfe, C., and S. Russell. 1997. The Role of Subject Leaders in Monitoring the Work of Teachers in Secondary Schools: The Quest for Consistency?. Paper presented at the British Educational Research Association Annual Conference, York, 11-14 September (online). Accessed September 17, 2015. http://www.leeds.ac.uk/educol/documents/000000477.htm.

Miles, M.B., and A.M. Huberman. 1994. Qualitative Data Analysis. $2^{\text {nd }}$ ed. Thousand Oaks, CA: Sage. 
Nasa, A., S. Pilay, and A. Vijain-Dren. 2014. International School Boom. The New Strait Times (online). Accessed October 20, 2014. https://www.pressreader.com/malaysia/new-straitstimes/20170423/281479276298177.

Office for Standards in Education (Ofsted). 1996. "Leadership and Management." HMI 42-43. London: The Stationery Office Limited.

Office for Standards in Education (Ofsted). 2015. "Middle Leadership." HMI 78-79. London: Ofsted.

Programme for International Student Assessment 2017. About (online). Accessed January 10, 2017. http://www.oecd.org/pisa/aboutpisa/.

Punch, K.F. 2009. Introduction to Research Methods in Education. London: Sage.

Ramey, M. 2013. The international school scene in Malaysia: an overview. In The Expat Education Guide (online). Accessed December 23, 2014. http://www.theexpatgroup.com/magazine/Education-Guide-2013.pdf.

Robson, C. 2002. Real World Research: A Resource for Social Scientists and Practitioner-researchers. Oxford: Blackwell Publishing.

School Advisor. 2017. International schools (online). Accessed January 8, 2017. http://schooladvisor.my/international-schools.

School Malaysia Early Childhood and Pre-Tertiary Education. 2013. Study opportunities at international schools (online). Accessed July 20, 2016. http://www.schoolmalaysia.com/resources/intl_school.php.

Southworth, G. 2002. "Instructional Leadership in Schools: Reflections and Empirical Evidence." School Leadership \& Management (22) 1:73-91.

Tam, A.C.F. 2010. "Understanding the Leadership Qualities of a Head of Department Coping with Curriculum Changes in a Hong Kong Secondary School." School Leadership \& Management 30 (4):367-386. doi: $10.1080 / 13632434.2010 .497480$.

The Star Online. 2013. Number of international schools set to exceed target (online). Accessed January 2017. http://www.thestar.com.my/News/Nation/2012/07/20/Number-of-internationalschools-set-to-exceed-target.aspx.

Turner, C. 2000. "Learning about Leading a Subject Department in Secondary Schools: Some Empirical Evidence". School Leadership \& Management 20 (3):299-313. doi: 10.1080/13632430050128336.

Waddington, D. 2004. "Participant Observation." In Essential Guide to Qualitative Methods in Organisational Research, edited by C. Cassell and G. Symon, 154164. London: Sage.

Weller, L.D. 2001. "Department Heads: The Most Underutilised Leadership Position." NASSP Bulletin 85 (625):73-81.

Wise, C. 2001. "The Monitoring Role of the Academic Middle Manager in Secondary Schools." Educational Management and Administration 29 (3):333-341. doi: 10.1177/0263211X010293007.

Wise, C., and N. Bennett. 2003. The Future Role of Middle Leaders in Secondary Schools: A Survey of Middle Leaders in Secondary Schools in England. Nottingham: National College for School Leadership (NCSL) (online). Accessed August 22, 2016. http://oro.open.ac.uk/8536/1/the-future-role-of-middleleaders-in-secondary-schools.pdf. 
Wise, C., and T. Bush. 1999. "From Teacher to Manager: The Role of the Academic Middle Manager in Secondary Schools." Educational Research 41 (2):183-195. doi: $10.1080 / 0013188990410206$.

Wong, C., P. Wong, and K.Z. Peng. 2010. "Effect of Middle-level Leaders and Teacher Emotional Intelligence on School Teachers' Job Satisfaction: The Case of Hong Kong." Educational Management \& Administration 38 (1):59-70. doi: $10.1177 / 1741143209351831$.

Xie, D., and J. Shen. 2013. "Teacher Leadership at Different School Levels: Findings and Implications from the 2003-04 Schools and Staffing Survey in US Public Schools." International Journal of Leadership in Education: Theory \& Practice 16 (3):327-348. doi: 10.1080/13603124.2012.690452. 